microvessels reaction for ischemia/reperfusion by recombinant erythropoietin. Kubanskij nauchnyj medicinskij vestnik. - Kuban Scientific Medical Journal. 2014;144(2):9-11.

7. Danilenko L. M., Pokrovsky M. V., Tatarenkova I. A., Elagin V. V., Bratchikov O. I. Pharmacological preconditioning of resveratrol in ischemic/ reperfusion injury: the role of nitric oxide. Kubanskij nauchnyj medicinskij vestnik. Kuban Scientific Medical Journal. 2015;155(6):35-38.

8. Nastos C., Kalimeris K., Papoutsidakis N., Tasoulis M. K., Lykoudis P. M., Theodoraki K., Nastou D., Smyrniotis V., Arkadopoulos N. Global consequences of liver ischemia/ reperfusion injury. Oxid. Med. Cell. Longev. 2014;1-13. https://doi.org/10.1155/2014/906965

9. Karpishchenko A. I. Handbook. Medical Laboratory Technology. Sankt-Petersburg: Intermedika, 2002.
10. Bradford M. M. A rapid and sensitive method for the quantitation of microgram quantities of protein utilizing the principle of protein-dye binding. Anal. Biochem. 1976;72:248-254.

https://doi.org/10.1016/0003-2697(76)90527-3

11. Dominko K., Đikić D. Glutathionylation: a regulatory role of glutathione in physiological processes. Arh. Hig. Rada. Toksikol. 2018;69:1-24

https://doi.org/10.2478/aiht-2018-69-2966

12. Kulinsky V. I., Kolesnichenko L. S. The glutathione system. II. Other enzymes, thiol-disulfide metabolism, inflammation, and immunity, functions. Biochemistry (Moscow) Supplement. Series B: Biomedical chemistry. 2009;3(3):211-220.

https://doi.org/10.1134/S1990750809030019

About authors:

Popov Konstantin Andreevich, PhD, Assistant of the department of fundamental and clinical biochemistry; tel.: +79288824941; e-mail: naftalin444@mail.ru

Bykov Ilia Mikhaylovich, MD, PhD, Professor, Head of department of fundamental and clinical biochemistry; tel.: +79182125530; e-mail: ilya.bh@mail.ru

Tsymbalyuk Igor Yuryevich, Laboratory assistant of department of Surgery № 2; tel.: +79284300769; e-mail: igor_ts@inbox.ru Bykov Mikhail Ilyitch, DMSc, associate professor of the Department of Surgery № 1; tel.: +79183596296; e-mail: bikov_mi@mail.ru

(c) Group of authors, 2018

UDC 616.20.06

DOI - https://doi.org/10.14300/mnnc.2018.13097

ISSN - 2073-8137

\title{
DRUG INDUCED PATOMORPHOSIS IN PARODONT AND ENVIRONMENTAL BONE TISSUE IN EXPERIMENTAL USE OF CORTICOSTEROIDS
}

\author{
Tsygan V. N. ${ }^{1}$, Shulenin K. S. ${ }^{1}$, Koskin S. A. ${ }^{1}$, Kovalevsky A. M. ${ }^{1}$,
} Borodulina I. I. ' ${ }^{1}$, Risovanniy S. I. ${ }^{2}$, Sirak S. V. ${ }^{3}$, Shchetinin E. V. ${ }^{3}$

${ }^{1}$ Military Medical Academy named after S. M. Kirov, Saint Petersburg, Russian Federation

2 Kuban State Medical University, Krasnodar, Russian Federation

3 Stavropol State Medical University, Russian Federation

\section{АЕКАРСТВЕННЫЙ ПАТОМОРФОЗ В ПАРОАОНТЕ И ОКРУЖАЮЩЕЙ КОСТНОЙ ТКАНИ ПОА ВОЗАЕЙСТВИЕМ КОРТИКОСТЕРОИАОВ В ЭКСПЕРИМЕНТААЬНЫХ УСАОВИЯХ}

\author{
В. Н. Цыган ${ }^{1}$, К. С. Шуленин ${ }^{1}$, С. А. Коскин ${ }^{1}$, А. М. Ковалевский ${ }^{1}$, \\ И. И. Бородулина ${ }^{1}$, С. И. Рисованный ${ }^{2}$, С. В. Сирак ${ }^{3}$, Е. В. Щетинин ${ }^{3}$ \\ 1 Военно-медицинская академия им. С. М. Кирова, Санкт-Петербург, \\ Российская Фелерация \\ 2 Кубанский госуАарственный МеАицинский университет, КрасноАар, \\ Российская ФеАерация \\ ${ }^{3}$ Ставропольский госуАарственный меАицинский университет, \\ Российская ФеАерация
}

This study was undertaken to evaluate the structure of bone and soft tissues of the rabbit oral cavity during and after long-term corticosteroid therapy. Osteoporotic changes in bone tissue were noted from the 12th day after the beginning of the experiment and progressed to the 30th day of the use of glucocorticoids. Dentin and tooth enamel were resistant to the action of the hormone. After the abolition of the 30-day course of hydrocortisone, normal structures were restored by day 16, and by the end of the experiment (day 30), there were no pathological changes in the bone or soft tissues of the teeth. Subsequently, the predentin zone was restored. These changes in bone tissue after the cessation of limiting therapy are reversible, which indicates the need for a more critical attitude towards those patients taking corticosteroids as an antiinflammatory therapy. 
Представлены результаты оценки структуры костной ткани и тканей зубов кроликов при длительной кортикостероидной терапии и при ее отмене. Изменения в костной ткани в виде остеопороза отмечались с 12 дня после начала эксперимента и прогрессировали к 30 дню использования глюкокортикоидов. Устойчивыми к действию гормона оказались дентин и эмаль зубов. После отмены 30-дневного курса гидрокортизона наблюдалось восстановление структур к 16 дню, а к концу эксперимента (30 день) отсутствовали какие-либо патологические изменения в костной ткани и в тканях зуба. Позже других восстанавливалась зона предентина. Указанные изменения костной ткани после прекращения лимитирующей терапии обратимы, что диктует необходимость более критичного отношения к состоянию пациентов, принимающих кортикостероиды в качестве противовоспалительной терапии.

Ключевые слова: кортикостероидная терапия, остеопороз, костная ткань

For citation: Tsygan V. N., Shulenin K. S., Koskin S. A., Kovalevsky A. M., Borodulina I. I., Risovanniy S. I., Sirak S. V., Shchetinin E. V. DRUG INDUCED PATOMORPHOSIS IN PARODONT AND ENVIRONMENTAL BONE TISSUE IN EXPERIMENTAL USE OF CORTICOSTEROIDS. Medical News of North Caucasus. 2018;13(3):529-533.

DOI - https://doi.org/10.14300/mnnc.2018.13097

Для цитирования: Цыган В. Н., Шуленин К. С., Коскин С. А., Ковалевский А. М., Бородулина И. И., РисованНЫЙ С. И., СИрак С. В., ЩЕТИНИн Е. В. ЛЕКАРСТВЕННЫЙ ПАТОМОРФОЗ В ПАРОДОНТЕ И ОКРУЖАЮЩЕЙ КОСТНОЙ ТКАНИ ПОД ВОЗДЕЙСТВИЕМ КОРТИКОСТЕРОИДОВ В ЭКСПЕРИМЕНТАЛЬНЫХ УСЛОВИЯХ. МеДИЦИНСКИЙ ВеСТНИК Северного Кавказа. 2018;13(3):529-533. XXX. DOI - https://doi.org/10.14300/mnnc.2018.13097

A long with their pronounced anti-inflammatory and immunomodulatory properties, which influence all metabolic forms, glucocorticoids (GC) have a wide range of adverse effects that are dependent on the dose and duration of application. The most commonly used form of GC therapy is limited therapy - when drugs are applied for several weeks to several months in non-physiological doses, their influence on bone metabolism is extensive; in particular, these effects include the emergence of generalized osteoporosis, which can lead to the formation of spontaneous fractures $[1,2,3]$.

Animal experiments have been performed to study morphological changes of the teeth during application of GC therapy. In particular, inhibition of the globular calcification of the dentinogenic zone of the upper incisors has been noted [4], as well as a sharp expansion of pulpal vessels and instances of hemorrhage $[5,6,7]$. However, after the introduction of the hormone, bone formation was observed $[8,9]$. Information regarding the timing and nature of changes in the tissues of the jaw and teeth under the influence of corticosteroid drugs is incomplete. Structural rearrangements of the periapical tissues of the jaw and hard tissues of the teeth that occur after the cessation of limited therapy with prednisolone $(1 \mathrm{mg} / \mathrm{kg} /$ day) or hydrocortisone (4-5 mg/kg/day) have not been extensively studied. However, such information is needed to substantiate, both with and after the abolition of GC, therapeutic approaches that involve the uncontrolled prescription of medications with unproven effects.

The purpose of the study was to study drug pathomorphosis in hard tissues of the teeth and surrounding tissues with the application of GC, as well as after the abolition of corticosteroids.

Material and Methods. Two series of experiments were performed. The first series studied changes in the teeth and surrounding tissues following the administration of corticosteroid preparations to 25 rabbits. The second series studied changes in these tissues after drug withdrawal, using 28 rabbits. In both series of experiments, rabbits underwent intramuscular administration of hydrocortisone for 30 days: $5 \mathrm{mg} / \mathrm{kg}$ body weight. Rabbits in the first series were sacrificed for analysis at $2,6,9,12,16,20,25$, and 30 days from the beginning of the administration of the preparation; rabbits in the second series were sacrificed for analysis at 2, 6,
$12,16,20,25$, and 30 days after drug discontinuation. For histological examination, teeth were harvested with surrounding tissues. The material was fixed in $12 \%$ neutral formalin for 7 days, decalcified in Trilon-B, subjected to ascending concentrations of alcohol exposure and poured into celloidin. Morphological changes were judged on the basis of preparations stained with hematoxylin and eosin, in accordance with the method of Mallory and Masson.

Data Processing. Microscopic analysis of the sections was performed on a digital microscope with an integrated Olympus BX45 camera. Morphometric studies were performed using Video-Test Morphology 5.1 software for Windows. The resulting digital data were analyzed using Student's t-test in Primer of Biostatistics 4.03 for Windows. $p<0.05$ was considered to indicate statistical significance.

Ethical standards. Animal experiments were performed in accordance with the principles of good laboratory practice (National Standard «Good Laboratory Practices» GOST R 53434-2009), «International recommendations for conducting animal biomedical research» (1985), and the Rules of Laboratory Practice in the Russian Federation (Order of the Ministry of Health of the Russian Federation № 267 of June 19, 2003).

Results and Discussion. In the first series, histological analysis of the jaws and teeth on the 2 nd day of the experiment showed no changes in the hard tooth tissues. The bony substance of the jaw was somewhat homogenized, and an excessive number of Ebner lines were apparent. No changes were detected on days 6 and 9. Pulp and periodontal vessels were full-blooded; in some, stasis phenomena were noted. On the surface of the bone, facing the hole, there were small lacunae. Within the pale stained bone substance, small round-oval cavities were formed, comprising a soft fibrous tissue. Some cavities overflowed with capillaries. The walls of the Haversian canals were intensively stained.

At days 9 and 16 after the beginning of the experiment, the overall structure of the hard tooth tissues persisted, although the predentin zone became poorly discernible; the dentin exhibited more pale dye staining (Fig. 1a). The blood supply to the capillaries of the pulp remained high; in some places, small focal hemorrhages were detected. In the root portions of the teeth, there was partial destruction of cellular elements in the pulp, as well as disorganization of the intercellular matrix with de- 
struction of the collagen fibers (Fig. 1). Bone surrounding the teeth exhibited significantly pronounced Ebner lines and Haversian canals with sharply hyperchromic walls. In comparison with the previous observations, the number and size of the cavities increased within the bone. Separate small osteoclasts were located in separate cavities.
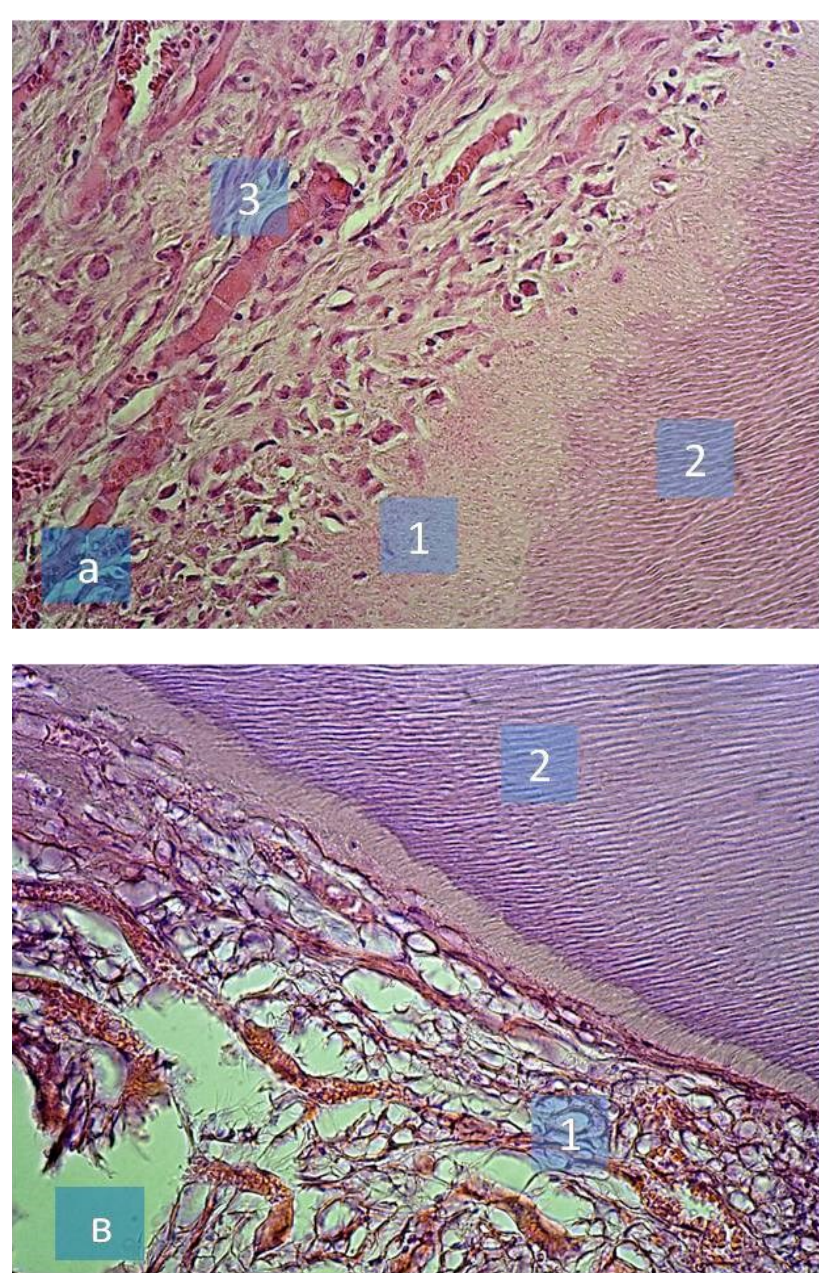

Fig. 1. Micro preparations. Pulp of the tooth on days 9 (a) and 16 (b) using corticosteroid: a - focal destruction of predentin (1), dentin zone (2), decay of pulp (3). Staining with hematoxylin and eosin. Ok. 40, Obj. 10; b - edema and disorganization of pulp tissues (1). Staining with hematoxylin and eosin. Ok. 20, Obj. 10

On day 20 , the osteon pattern was almost undetectable in the bone tissue; osteoporotic changes in the bone substance surrounding the teeth were pronounced. In some areas, the bone substance appeared as small, discrete pale staining beams.

Changes in the structure of the tooth and surrounding bone tissue on days 25 and 30 of the experiment did not differ from those observed earlier in the experiment.

In the second series, histological analysis of the jaws and teeth on day 2 (after the drug was discontinued) showed that the changes described above in the tissues of the teeth and jaws persisted. On days 6 and 9, the walls of the Haversian canals became intensively stained in the bone tissue surrounding the teeth. On days 12 and 16, the dentin became basophilic, and the zone of predentin was not detected. Blood supply to the capillaries was moderate. The lengths of endothelial cells in the tissues of the periodontal mandible were $72.4 \pm 7.18-$ $104.8 \pm 12.85 \mu \mathrm{m}$. The thicknesses of endothelial cells in the tissues of periodontium of the upper jaw were
$76.4 \pm 9.35-108.8 \pm 12.6 \mu \mathrm{m}$; those in the gum of the lower jaw were $34.6 \pm 4.75-68.3 \pm 11.64 \mu \mathrm{m}$. The area of blood vessels within the pulp of the teeth of the upper and lower jaws also was significantly different, compared with that of the control group (Table). A pronounced vacuolization was observed in the odontoblasts. During the same period of the experiment, proliferation of connective tissue elements of the periosteum became especially noticeable in the bone substance of the jaws (Fig. 2). Cavities formed earlier under the influence of cortisone, gradually filled with newly formed bright pink bone substance with a foundation consisting of large osteoblasts.

The area of blood vessels of the pulp of the teeth of the upper and lower jaws $\left(\mu^{2}\right)$

\begin{tabular}{|l|c|c|c|c|}
\hline \multirow{2}{*}{ Day } & \multicolumn{2}{|c|}{ Arterioles, $\mathrm{M} \pm \mathrm{m}$} & \multicolumn{2}{c|}{ Venules, $\mathrm{M} \pm \mathrm{m}$} \\
\cline { 2 - 5 } & Upper jaw & Lower jaw & Upper jaw & Lower jaw \\
\hline Control & $49.97 \pm 3.15$ & $45.94 \pm 3.15$ & $51.63 \pm 5.55$ & $50.53 \pm 7.86^{*}$ \\
\hline 2 & $29.16 \pm 2.87^{*}$ & $25.44 \pm 1.71^{*}$ & $42.93 \pm 4.78^{*} \&$ & $33.13 \pm 4.59^{*}$ \\
\hline 20 & $33.13 \pm 3.17^{*}$ & $30.46 \pm 2.75^{*}$ & $31.52 \pm 2.45^{*}$ & $35.17 \pm 6.79^{*}$ \\
\hline 30 & $39.49 \pm 1.45^{*}$ & $32.16 \pm 1.27^{*}$ & $34.25 \pm 2.44^{*}$ & $31.25 \pm 4.35^{*}$ \\
\hline
\end{tabular}

Note: statistical significance of the differences with the control: ${ }^{*}-p<0.05$; between the upper and lower jaws: \& $-p<0.05$.
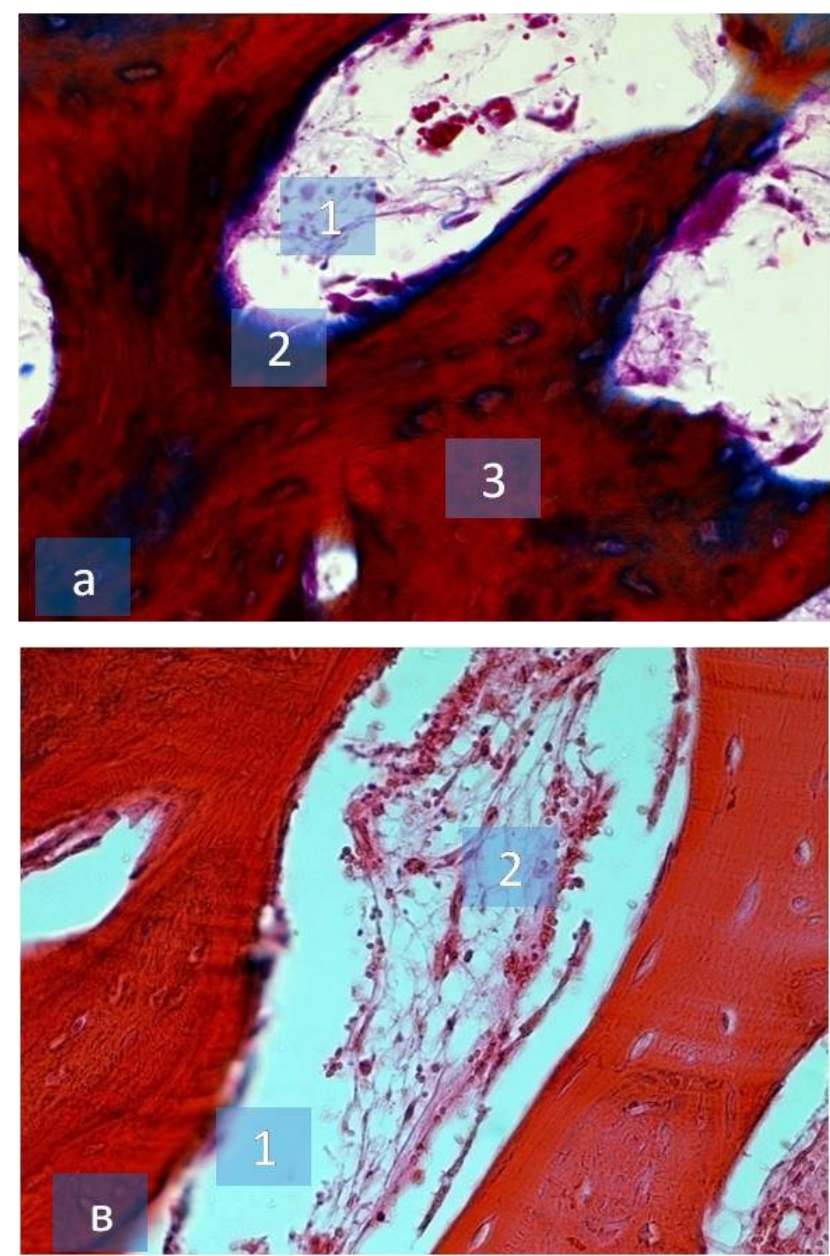

Fig. 2. Micro preparations. Bone tissue on days 12 (a) and 16 (b) after corticosteroid withdrawal: a - formation of reticulofibrous bone tissue, proliferation of connective tissue elements (1) of periosteum (2) in bone jaw material (3). Coloring Mallory. Ok. 10, Obj. 40; b - cavity (1), formed under the influence of cortisone, filled with newly formed bone substance (2). Staining with hematoxylin and eosin. Ok. 20, Obj. 10 
By day 20, the hard tissues of the teeth did not differ much from the corresponding normal tissues; however, the predentin zone was almost undetectable. In the bone tissue of the jaws, small cavities, «lined» with a layer of osteoid substance, were sporadically preserved. Bony beams became massive; osteoblasts were located on the surface of the beams.

On days 25 and 30 after cortisone abolition, the histological structures of the teeth and surrounding bone tissue were as follows. The layer of predentin was restored; petrification of the dentinal tubules increased (Fig. 3); dentinal spheres appeared, although vacuolization remained near odontoblasts; cavities in the bone material were completely filled with newly formed osteoid tissue; and dentinal tubules were greatly expanded, many at the beginning of dichotomous division, due to the deposition of lime. The tubules were highly convoluted, but retained their structural anatomical structure.
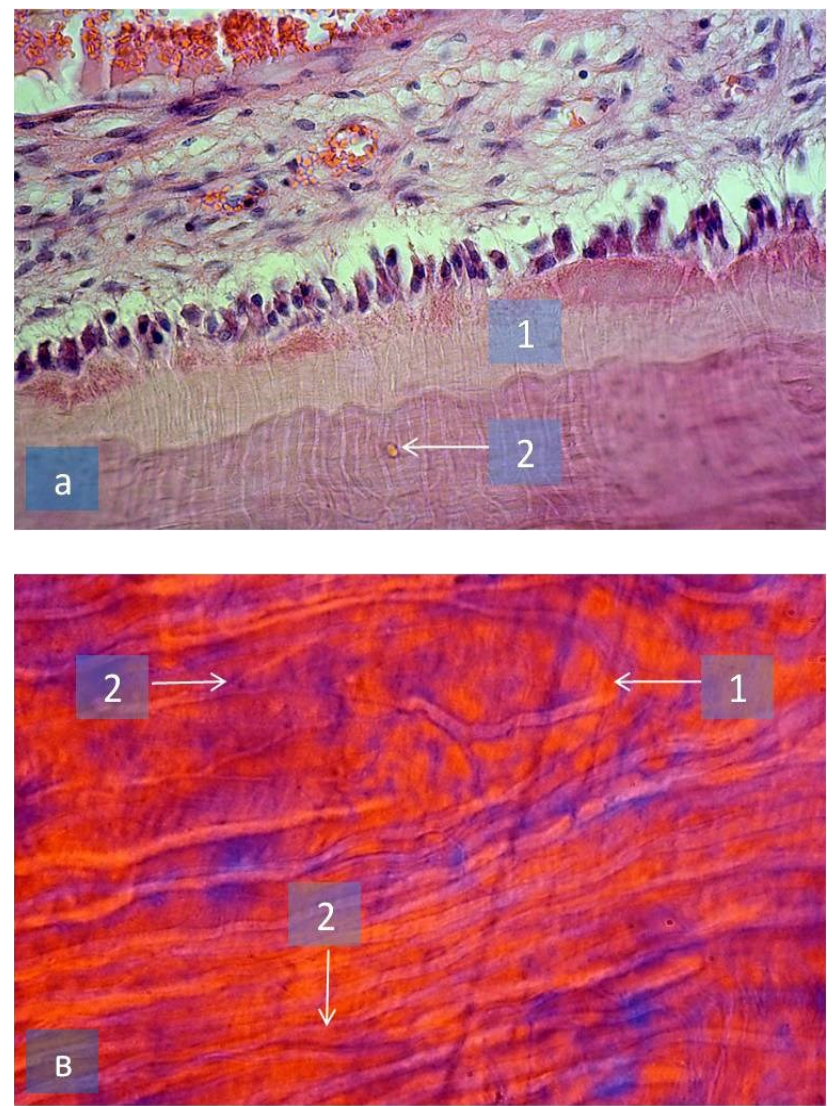

Fig. 3. Micro preparations. Structure of dentin on days 25 (a) and 30 (b) after corticosteroid withdrawal: a - restoration of the predentin layer (1), petrification of the dentinal tubules (2).

Staining with hematoxylin and eosin. Ok. 40, Obj. 10; b - convoluted dentinal tubules (1) with signs of dichotomous division (2). Masson coloring. Ok. 100, Obj. 10

These experiments indicated that enamel and dentin were relatively durable with respect to the effect of cortisone. Moreover, the introduction of cortisone caused a disruption in the distribution of lime salts in the dentin and necrobiotic changes in odontoblasts.

Changes in the pulp throughout the experiment were consistent, comprising fullness, swelling of the tissue, and pyknosis of the vascular endothelial nuclei.

In the bone tissue surrounding the teeth, the most characteristic change was the gradual development of osteoporosis, which reached a peak on days 20 and 25 day of the experiment. Calcareous salts were excreted from the bone substance mainly through Haversian canals, as evidenced by excessive staining of the canal walls with hematoxylin.

The observed changes can be subdivided into early and late reactive changes in bone tissue, in response to the administration of corticosteroid preparations. Importantly, some histological changes (especially those that occur early during corticosteroid administration), became evident only with histological examination and could not be clinically detected. However, these changes led to disruption of structure and function in tissues of the teeth and bone with prolonged or massive corticosteroid therapy; thus, they are valuable in the overall evaluation of a particular pathological condition.

The results of the second series of experiments convincingly showed that the disruptions of oral structured related to corticosteroid therapy are completely reversible, although this effect may be limited to short courses of corticosteroid therapy. Hard tissues of teeth, because of their minimal exposure to the hormone, almost completely regained their natural structures by days 9 and 12 after discontinuation of the drug. By the same date, the reversal of osteoporosis reached a significant extent.

Restoration of periapical bone tissues was primarily mediated through enhanced proliferation of cellular cambial elements possessing osteogenic potencies, followed by ossification of the newly formed osteoid tissue. The vacuolization of odontoblasts noted in the experiments, which followed the restoration of the dentin structure, confirmed the physiological essence of this process, which completed the proliferation of hard tissues of the teeth.

Osteoporosis is a well-recognized complication of periodontal pathology and changes in the bone tissue environment in a variety of diseases. In a prior study [12], increased bone turnover, inflammation, and low vitamin $D$ levels were shown to be important in the pathophysiology of ankylosing spondylitis osteoporosis in 128 outpatients.

Investigations of the effects of GC on bone mineral density showed negative effects on lumbar spine bone mineral density, but no effect on hip bone mineral density [13]. Moreover, in ankylosing spondylitis, tumor necrosis factor inhibitor was associated with improved lumbar spine and hip bone mineral density.

A prior study [14] of the prevalence of osteoporosis and fractures in axial spondyloarthritis showed that these vary between 11.7-34.4\% and 11-24.6\%, respectively. The main reason for osteoporosis in that study was steroid administration. Additional well-designed patient studies must be performed to investigate bone quality, bone microarchitecture and fractures, and disease-associated factors.

Conclusions. The study showed the possibility of developing, under the influence of corticosteroids, a number of undesirable phenomena; these included various disorders in the structure of the teeth and surrounding tissues. Changes in the structure of teeth and tissue that develop with corticosteroid therapy, by their nature, comprise manifestations of osteoporosis obtained under experimental conditions in other animals, following the introduction of higher doses of hormones [4, 8]. These changes in teeth and jaws after reversal of limiting therapy are reversible, 
which indicates the need for a more critical attitude toward patients taking corticosteroids as an antiinflammatory therapy $[10,11]$, as well as more objective justification (with a high level of evidence) for prescribing medications to correct undesirable effects of GC.

\section{Disclosures:}

The authors declare no conflict of interest.

Acknowledgements. We thank Ryan Chastain-Gross, Ph.D., from Edanz Group (www.edanzediting.com/ac) for editing a draft of this manuscript.

\section{References}

1. Golovach I. Y. Glucocorticoid-induced osteoporosis: historical aspects and modern approaches to prevention and treatment. Farmateka. - Pharmatec. 2015;(4):50-55.

2. Compston J., Cooper A., Cooper C. UK clinical guideline for the prevention and treatment of osteoporosis. Arch. Osteoporos. 2017;12(1):43.

3. Subramaniam S., Ima-Nirwana S., Chin K.-Y. Performance of osteoporosis self-assessment tool (OST) in predicting osteoporosis - a review. Int. J. Environ. Res. Pub. Health. 2018;15(7):1445

https://doi.org/10.3390/ijerph15071445

4. Sirak S. V., Shchetinin E. V., SirakA. G. Pathomorphological changes of dental pulp in experimental osteoporosis. Medical News of North Caucasus. 2016;11(2):210-213. https://doi.org/10.14300/mnnc.2016.11039

5. Basov A. A., Baryshev M. G., Bykov I. M., Pavljuchenko I. I., Dzhimak S. S. [et. al.] The effect of water with a modified isotope composition on the intensity of free radical processes in an experiment on laboratory animals. Allergologija i immunologija. - Allergology Immunology. 2012;13(4):314-320.

6. Kulakov A. A., Goldshtein D. B., Gigoryan A. S., Rzhaninova A. A., Alekseeva I. S. [et. al.] Clinical study of the efficiency of combined cell transplant on the basis of multipotentmesenchymal stromal cells of adipose tissue in patients with severe deficiency of bone in the upper and lower jaw. Kletochnie technologii v biologii i medicine. Cell technologies in biology and medicine. 2008;(4):206210.

7. Shchetinin E. V., Sirak S. V., Koshel I. V., Kobylkina T. L., Dygov E. A. Morphological characteristics of periodontal tissues in experimental osteoporosis. Medical News of North Caucasus. 2016;11(3):373-376

https://doi.org/10.14300/mnnc.2016.11081
8. Sirak S. V., Shchetinin E. V., Bobryshev D. V., Fritsch T., Giesenhagen B. [et. al.] Osteoporotic sheep mandibular model for comparative alveolar bone healing research. Medical News of North Caucasus. 2017;12(3):284-289. https://doi.org/10.14300/mnnc.2017.12091

9. Murshid S. A. The role of osteocytes during experimental orthodontic tooth movement: A review. Arch. Oral Biol. 2017;73:25-33

https://doi.org/10.1016/j.archoralbio.2016.09.001

10. Myles T. D. Steroids - Plenty of benefits, but not without risk. Obstet. Gynecol. 2011;117(2-2):429-430. https://doi.org/10.1097/AOG.0b013e31820711f0

11. Hochberg $Z$. Mechanisms of steroid impairment of growth. Hormone Res. 2002;58(Suppl. 1):33-38. https://doi.org/10.1159/000064764

12. Arends S., Spoorenberg A., Bruyn G. A. W., Houtman P. M., Leijsma M. K. [et al.] The relation between bone mineral density, bone turnover markers, and vitamin D status in ankylosing spondylitis patients with active disease: a cross-sectional analysis. Osteoporos Int. 2011:22:1431-1439. https://doi.org/10.1007/s00198-010-1338-7

13. Siu S., Haraoui B., Bissonnette R., Bessette L., Roubille C. [et al.] Meta-Analysis of Tumor Necrosis Factor Inhibitors and Glucocorticoids on Bone Density in Rheumatoid Arthritis and Ankylosing Spondylitis Trials. Arthritis Care Res. 2015;67(6):754-764. https://doi.org/10.1002/acr.22519

14. Ramíreza J., Nieto-Gonzálezb J. C., Rodríguezc R. C., Castañedad S., Carmona L. Prevalence and risk factors for osteoporosis and fractures in axial spondyloarthritis: A systematic review and meta-analysis. Sem. Arthritis Rheumatism. 2018;48(1):44-52. https://doi.org/10.1016/j.semarthrit.2017.12.001

\footnotetext{
About authors:

Tsygan Vasilii Nikolaevich, MD, PhD, Professor, Head of Department of Pathophysiology; tel.: +79650039715; e-mail: vn-t@mail.ru

Shulenin Konstantin Sergeevich, MD, PhD, Professor of Department of Naval Therapy; tel.: +79045572338; e-mail: shulenink@mail.ru

Koskin Sergey Alekseevich, MD, PhD, Professor of Department of Ophthalmology; tel.: +79219382588; e-mail: eyemillenium@mail.ru

Kovalevsky Aleksandr Mechislavovich, MD, PhD, Associate Professor of Department of Therapeutic Dentistry tel.: +79119765558; e-mail: endy_taker@mail.ru

Borodulina Irina Ivanovna, MD, PhD, Professor of Department of Maxillofacial Surgery and Surgical Dentistry; tel.: +79602598162; e-mail: borodulina59@mail.ru

Risovanniy Sergey Isaakovich, MD, PhD, Professor, Professor of Department of Dentistry;

tel.: +78612623896; e-mail: stomatologia.fpk@gmail.com

Sirak Sergey Vladimirovich, MD, PhD, Professor, Head of Department of Dentistry;

tel.: +78652350551; e-mail: sergejsirak@yandex.ru

Shchetinin Evgeny Vyacheslavovich, MD, PhD, Professor, Head of Department of Pathophysiology;

tel.: +78652352684; e-mail: ev.cliph@rambler.ru
} 